\title{
Effect of high-energy diets on live weight change in sow *
}

\author{
L. Snehal', V. Dildeep ${ }^{2}$, K. Ally ${ }^{3}$, A.P. Usha ${ }^{4}$, K.S. Ajith ${ }^{5}$ \\ Department of Animal Nutrition, College of Veterinary and Animal Sciences, \\ Mannuthy, Thrissur, Kerala - 680651. \\ Kerala Veterinary and Animal Sciences University, Pookode, Wayanad
}

Citation: Snehal, L., Dildeep, V., Ally, K., Usha, A.P. and Ajith, K.S. 2021. Effect of high-energy diets on live weight change in sow. J. Vet. Anim. Sci. 52(1): 88-91.

DOI: https://doi.org/10.51966/jvas.2021.52.1.88-91

Received: 23.07.2020

Accepted: 30.08 .2020

Published: 01.01.2021

\begin{abstract}
An experiment was carried out on Large White Yorkshire sows for a duration of 63 days at the Centre of Pig Production and Research, Mannuthy to elucidate the impact of higher feed energy levels through corn oil supplementation. Eighteen Large White Yorkshire pregnant sows were selected three weeks before the anticipated date of parturition and were divided into three uniform groups of six each and were allocated the treatments, T1\{(Control ration (18\% CP and $3280 \mathrm{kcal} / \mathrm{kg}$ ME as per ICAR, 2013)\}, T2\{(Control ration $+1 \%$ Corn oil $(\mathrm{w} / \mathrm{w})(18 \%$ CP and 3365 $\mathrm{kcal} \mathrm{ME} / \mathrm{kg}$ feed)\} and T3 $\{$ (Control ration $+2 \%$ Corn oil $(w / w)(18 \% \mathrm{CP}$ and $3450 \mathrm{kcal} \mathrm{ME} / \mathrm{kg}$ $f e e d)\}$. The dry matter intake of the sows of the three groups was similar ( $p>0.05)$. At 42 days of lactation, the lactational loss in body weight of sows was statistically similar ( $p>0.05)$.
\end{abstract}

Keywords: pregnant sows, lactating sows, corn oil, dietary energy

In sows, dietary energy has a decisive role to play especially during gestation and lactation. It aids in foetal and maternal membrane development and is also deposited as lipids in maternal tissue, which will be mobilized later on during lactation. Adequate feed intake and body condition during gestation can reduce lactational body weight loss in sows (Schenkel et al., 2010). Excessive mobilization of maternal tissue during lactation can result in extreme weight loss in sows and subsequent reproductive complications (Quensel et al., 2008). Supplementation of extra energy during gestation has been reported to counter extreme lactational body weight loss and back fat reduction in sows (Wang et al., 2016). Many lipid sources including vegetable oils and animal fats have been used in sows as feed supplements. Only few studies have been done with corn oil as an

${ }^{*}$ Forms part of the MVSc thesis submitted by the first author to the Kerala Veterinary and Animal Sciences University, Pookode, Wayanad, Kerala.

1. M.V.Sc. student and corresponding author, Department of Animal Nutrition, snehallokhande989@gmail.com, 7208020251

2. Associate Professor

3. Professor and Head

4. Professor and Head, Centre for Pig Production and Research

5. Assistant Professor

Copyright: (C) 2021 Sneha et al. This is an open access article distributed under the terms of the Creative Commons Attribution 4.0 International License (http://creativecommons.org/licenses/by/4.0/), which permits unrestricted use, distribution, and reproduction in any medium, provided the original author and source are credited.

88 Effect of high-energy diets on live weight change... 
energy supplement in sow diet due to its high polyunsaturated fatty acid content. Taking into account, to its high digestibility and high content of antioxidants, carotenoids and conjugated linoleic acid, corn oil was studied with a view to evaluate its effect on feed intake and body weight of pregnant and lactating sows.

Eighteen Large White Yorkshire pregnant sows from the CentreforPigProduction and Research, Mannuthy were selected three weeks prior to their expected date of farrowing. The sows were divided into three groups of six each as uniformly as possible with regard to body weight $(204.65 \mathrm{~kg})$ and parity (first and second). They were dewormed with ivermectin suspension through feed before the start of the experiment. All the animals were housed under uniform management conditions and were fed twice daily. The animals were offered feed for one hour and the residual feed, if any, was collected and weighed daily and the moisture content was analysed to calculate the dry matter intake.

The feeding trial was done on pregnant sows selected three weeks prior to farrowing and extended till the $42^{\text {nd }}$ day of weaning of piglets. The three dietary treatments were formulated as per ICAR, 2013, as follows:

T1- Control ration (Ingredient composition as per Table 1) (18\% CP and $3280 \mathrm{kcal} \mathrm{ME} / \mathrm{kg}$ feed)

T2- Control ration + 1\% corn oil (w/w) (18\% CP and $3365 \mathrm{kcal} \mathrm{ME} / \mathrm{kg}$ feed)

T3- Control ration + $2 \%$ corn oil (w/w ) $(18 \%$ CP and $3450 \mathrm{kcal} \mathrm{ME} / \mathrm{kg}$ feed)

The sows of each group were fed with the corresponding treatment ration. A record of the daily feed intake of the animal was maintained throughout the experiment. Residue feed was collected, weighed and was analysed for moisture estimation. Body weights of the sows were recorded at the beginning of the experiment and thereafter at fortnightly intervals. Data collected on various parameters were analysed by Analysis of Variance (ANOVA) (Snedecor and Cochran, 1994).
The weekly feed intake and fortnightly body weight of the sows kept on the three diets are listed in Tables 2 and 3, respectively.

The initial and final dry matter intake $(\mathrm{kg} / \mathrm{d})$ of the sows kept on T1, T2 and T3 were 3.67, 3.57, 3.81 and 4.03, 4.12, 4.29 , respectively. There was no significant difference $(p>0.05)$ between sows of the three groups with respect to dry matter intake during the experimental period. Similar results were reported by Quiniou et al., (2008), whereas the feed intake was lowered with higher energy concentrations as suggested by reports of Prunier et al. (2001) and Jin et al. (2016). Increased feed intake observed with higher energy concentration was reported by Rosero et al., (2012). In the present study, the dry matter intake was not affected probably due to the restricted feeding practised. This agrees with results reported by Sulabo et al. (2010) who compared ad libitum and restricted feeding in sows fed on high-energy diets.

Table 1. Ingredient composition of control ration, \%

\begin{tabular}{|c|c|}
\hline Ingredients, \% & Control ration \\
\hline Yellow maize & 71 \\
\hline Soya bean meal & 25 \\
\hline Fat & 2 \\
\hline Salt & 0.5 \\
\hline Mineral mixture & 1.5 \\
\hline Total & 100 \\
\hline Nicomix AB2D3 ${ }^{1}$ & $25 \mathrm{gm}$ \\
\hline Nicomix BE ${ }^{2}$ & $25 \mathrm{gm}$ \\
\hline Zinc oxide ${ }^{3}$ & $45 \mathrm{gm}$ \\
\hline Oxylock antioxidant ${ }^{4}$ & $10 \mathrm{gm}$ \\
\hline Nicomix AB2D3 ${ }^{1}$ & $25 \mathrm{gm}$ \\
\hline
\end{tabular}

${ }^{1}$ Nicomix A, B2, D3, (Nicholas Piramal India Ltd, Mumbai) containing Vitamin A- 82,500 IU, Vitamin $\mathrm{B}_{2}-50 \mathrm{mg}$, Vitamin $\mathrm{D}_{3}-12000 \mathrm{IU}$ and Vitamin K-10 mg per gram

${ }^{2}$ Nicomix BE (Nicholas Piramal India Ltd, Mumbai) containing vitamin $\mathrm{B}_{1}-4 \mathrm{mg}$, Vitamin $\mathrm{B}_{6}-8 \mathrm{mg}$, Vitamin $B_{12}-40 \mathrm{mg}$, Niacin $-60 \mathrm{mg}$, Calcium pantothenate$40 \mathrm{mg}$ and Vitamin E- $40 \mathrm{mg}$ per gram.

${ }^{3}$ Zinc oxide (Nice Chemicals Pvt. Ltd., Kochi) containing $81.38 \% \mathrm{Zn}$

${ }^{4}$ Oxylock antioxidant (Vetline Ltd., Indore) contains Ethoxyquin, Butylated Hydroxy Toluene (BHT), Chelators and Surfactatant. 
Table 2. Weekly average feed intake of sows maintained on the three experimental rations on dry matter basis, kg.

\begin{tabular}{|c|c|c|c|c|c|}
\hline \multirow{2}{*}{ Weekly } & \multicolumn{3}{|c|}{ Treatments } & \multirow{2}{*}{ SEM value } & \multirow{2}{*}{ p-value } \\
\cline { 2 - 4 } & $\mathrm{T} 1$ & $\mathrm{~T} 2$ & $\mathrm{~T} 3$ & & $0.703^{\text {ns }}$ \\
\hline 1 & $3.67 \pm 0.21$ & $3.57 \pm 0.18$ & $3.81 \pm 0.22$ & 0.115 & $0.400^{\text {ns }}$ \\
\hline 2 & $3.41 \pm 0.16$ & $3.91 \pm 0.25$ & $3.61 \pm 0.33$ & 0.115 & $0.856^{\text {ns }}$ \\
\hline 3 & $3.09 \pm 0.26$ & $3.12 \pm 0.51$ & $3.37 \pm 0.32$ & 0.208 & $0.695^{\text {ns }}$ \\
\hline 4 & $1.85 \pm 0.16$ & $2.05 \pm 0.26$ & $2.06 \pm 0.13$ & 0.107 & $0.572^{\text {ns }}$ \\
\hline 5 & $2.56 \pm 0.27$ & $2.88 \pm 0.22$ & $2.50 \pm 0.30$ & 0.151 & $0.817^{\text {ns }}$ \\
\hline 6 & $2.75 \pm 0.43$ & $2.87 \pm 0.19$ & $3.05 \pm 0.34$ & 0.184 & $0.680^{\text {ns }}$ \\
\hline 7 & $3.25 \pm 0.49$ & $3.29 \pm 0.32$ & $3.69 \pm 0.31$ & 0.214 & $0.717^{\text {ns }}$ \\
\hline 8 & $3.74 \pm 0.38$ & $3.73 \pm 0.14$ & $3.98 \pm 0.10$ & 0.133 & $0.650^{\text {ns }}$ \\
\hline 9 & $4.03 \pm 0.24$ & $4.12 \pm 0.17$ & $4.29 \pm 0.19$ & 0.114 & 0 \\
\hline
\end{tabular}

${ }^{1}$ Mean of six values with SE

ns- Non significant $(p>0.05)$

Table 3. Fortnightly average body weight of sows maintained on three experimental rations, $\mathrm{kg}$

\begin{tabular}{|c|c|c|c|c|c|}
\hline \multirow{2}{*}{ Days } & \multicolumn{3}{|c|}{ Treatments $^{1}$} & \multirow{2}{*}{ SEM value } & p-value \\
\cline { 2 - 5 } & T1 & T2 & T3 & \\
\hline $\begin{array}{c}\text { 21 days before } \\
\text { farrowing }\end{array}$ & $202.33 \pm 12.08$ & $202.51 \pm 10.99$ & $209.12 \pm 16.86$ & 7.388 & $0.922^{\text {ns }}$ \\
\hline $\begin{array}{c}7 \text { days } \\
\text { before farrowing }\end{array}$ & $216.38 \pm 13.33$ & $231.52 \pm 10.78$ & $229.7 \pm 16.58$ & 7.644 & $0.703^{\text {ns }}$ \\
\hline At farrowing & $194.18 \pm 11.43$ & $210.05 \pm 10.13$ & $210.55 \pm 17.21$ & 7.437 & $0.621^{\text {ns }}$ \\
\hline $\begin{array}{c}\text { 14 days after } \\
\text { farrowing }\end{array}$ & $184.53 \pm 13.85$ & $198.43 \pm 9.58$ & $196.58 \pm 16.87$ & 7.61 & $0.744^{\text {ns }}$ \\
\hline $\begin{array}{c}\text { 28 days after } \\
\text { farrowing }\end{array}$ & $178.26 \pm 15.85$ & $198.18 \pm 8.63$ & $193.12 \pm 17.04$ & 8.036 & $0.603^{\text {ns }}$ \\
\hline $\begin{array}{c}\text { 42 days after } \\
\text { farrowing }\end{array}$ & $175.08 \pm 15.59$ & $195.39 \pm 11.59$ & $190.65 \pm 17.02$ & 8.357 & $0.612^{\text {ns }}$ \\
\hline
\end{tabular}

${ }^{1}$ Mean of six values with SE

ns- Non significant $(p>0.05)$

The initial and final average body weight $(\mathrm{kg})$ of the sows fed T1, T2 and T3 were 202.33, 202.51, 209.12 and 175.08, 195.39, 190.65 , respectively. There was no significant difference ( $p>0.05)$ among the sows of the three groups with respect to body weight during the experimental period. When compared with the supplemented groups T2 and T3. The results during the lactation period were in agreement with the reports of Long et al., (2010), Jin et al., (2016) and Rosero et al., (2012), who observed that sows fed with high-energy diet gained significantly more body weight and back fat during gestation whereas the body weight loss during suckling was not significantly affected.

Reports by Wang et al., (2016) and Cabezon et al., (2016) indicated that there were better gestational body weights and lesser lactational weight loss in sows supplemented with high-energy diets.

In the present study, the lactational weight loss was not different among the groups. Renaudeau and Noblet (2001), suggested that high-energy diets provide lipids to be transferred to lacteal glands and resulted in milk with a high lipid content and hence lactational loss was not affected. 
The dry matter intake of sows of the three groups was similar which indicated that high-energy diets had no effect on feed intake. At 42 days of lactation, the body weight of sows in the high-energy supplemented groups was numerically better; however, the lactational loss in body weight of sows was statistically similar.

\section{Reference}

Cabezon, F.A., Schinkel, A.P., PAS, Richert, B.T., Stewart K.R., Gandarillas, M. and Peralta, W.A. 2016. Analysis of lactation feed intakes for sows including data on environmental temperatures and humidity. The Professional Anim. Scientist. 32: 333-345.

ICAR [ Indian Council of Agricultural Research]. 2013. Nutrient requirements of animals - Pig (ICAR-NIANP) (3 $\left.3^{\text {rd }} \mathrm{Ed}\right)$. Indian Council of Agricultural Research, New Delhi, 22p.

Jin, S.S., Jung, S.W., Jang, J.C., Chung, W.L., Jeong, J.H. and Kim, Y.Y. 2016. Effects of dietary energy levels on the physiological parameters and reproductive performance of gestating gilts. Asian Australas. J. Anim. Sci. 29: 1004-1012.

Long, H.F., Ju, W.S., Piao, L.G. and Kim, Y.Y. 2010. Effect of dietary energy levels of gestating sows on physiological parameters and reproductive performance. Asian-Aust. J. Anim. Sci. 23: 1080-1088.

Prunier, A., Guardarrama, C.A. M., Mourot, J. and Quensel, H. 2001. Influence of feed intake during pregnancy and lactation on fat body reserve mobilization, plasma leptin and reproductive function of primiparous lactating sows. Reprod. Nutr. Dev. 41: 333-347.

Quensel H., Brossard L., Valacogne, A. and Quiniou, N. 2008. Influence of some sow characteristics on within-litter variation of piglet birth weight. Anim. 2: 1842-1849.

Quiniou N., Richard S., Mourot J., and Etienne M. 2008. Effect of dietary fat or starch supply during gestation and/or lactation on the performance of sows, piglets' survival and on the performance of progeny after weaning. Anim. 2: pp 1633-1644.

Renaudeau, D. and Noblet, J. 2001. Effects of exposure to high ambient temperature and dietary protein level on sow milk production and performance of piglets. J. Anim. Sci. 79: 1540-1548.

Rosero, D.S., van Heugten, E., Odle, J., Cabrera, R., Arellano, C. and Boyd, R.D. 2012. Sow and litter response to supplemental dietary fat in lactation diets high ambient temperatures. J. Anim. Sci. 90: 550-559.

Schenkel, A.C., Bernadi, M.L., Bortolozzo, F. P.and Wentz, I. 2010. Body reserve mobilization during lactation in first parity sows and its effect on second litter size. Livestock Sci. 132 :165-172.

Snedecor, G.W. and Cochran, W.G. 1994. Statistical Methods ( $8^{\text {th }}$ Ed.). The lowa state university press, Ames, lowa, USA, $314 p$.

Sulabo, R.C., Jacela, J.Y., Tokach, M.D, Dritz, S.S., Goodband, R.D., DeRouchey, J.M. and Nelssen, J.L. 2010. Effects of lactation feed intake and creep feeding on sow and pig performance. J. Anim. Sci. 88: 3145-3153

Wang, J., Yang, M., Cao, M., Lin, Y., Che, L., Veeramuthu, D., Al-Dhabi, N. A., Fang, Z., Xu, S., Feng, B., Liu, G. and Wu, D. 2016. Moderately increased energy intake during gestation improves body condition of primiparous sows, piglet growth performance, milk fat and protein output. Livestock Sci. 194: 23-30. 